\title{
The use of X-ray diffraction for phase identification of press hardened steels
}

\author{
Couto, C. P.; Costa, P. D. O. L.; Martinez, L. G.; Turrillas, X.; Rossi, J. L. \\ Instituto de Pesquisas Energéticas e Nucleares - IPEN - CNEN/SP \\ Av. Prof. Lineu Prestes, 2242 - Cidade Universitária - CEP 05508-00 - São Paulo - SP - Brazil \\ camila.puccicouto@gmail.com
}

\begin{abstract}
The numbers of hot stamped components have been steadily increasing in the automotive industry. Press hardened steels are generally used in hot stamping process since at the end of the process, the steel may achieve a tensile strength about $1500 \mathrm{MPa}$. The hot stamping process consists to heat the steel blank at total austenitization temperature and to transfer the blank into the press tooling for shaping and fast cooling to fully martensitic transformation. The transfer of the blank from the furnace to the press might promote at some extent, steel oxidation. The application of metallic coatings avoids this hindrance. The Al$\mathrm{Si}$ has been the most applied coating on steel. In parallel, alternative coatings such as $\mathrm{Zn}-\mathrm{Ni}$ have been developed. It is known that the heating causes chemical elements diffusion, which results in intermetallic formation between the elements presents in the coating and in the substrate. This study had the objective of characterizing hot stamped and coated 25MnB5 steel samples with $\mathrm{Al}-\mathrm{Si}$ and $\mathrm{Zn}-\mathrm{Ni}$, with $\mathrm{X}$ rays diffraction (XRD) technique. Some literature suggested phases such as Zn-Fe, Zn-Ni-Fe or Al-Fe-Si were not seen on XRD results. Nonetheless, X-ray diffraction detected the presence of $\mathrm{ZnO}$ and $\alpha-\mathrm{Fe}$ for $\mathrm{Zn}-\mathrm{Ni}$ coated steel plate and $\mathrm{Al}_{5} \mathrm{Fe}_{2}, \mathrm{AlFe}_{3}$ and $\alpha-\mathrm{Fe}$ for the Al-Si coated steel plate.
\end{abstract}

Key words: PHS, phase, X-ray diffraction.

\section{Resumo}

É crescente o número de componentes estampados a quente destinados a indústria automotiva. Os aços endurecidos por estampagem (PHS) são geralmente usados no processo de estampagem a quente porque ao final do processo o aço atinge resistência mecânica próxima a1500 MPa. O processo de estampagem a quente consiste em aquecer um blanque em temperaturas de total austenitização e transferi-lo do forno de aquecimento para uma prensa. Nesta prensa, ocorre a conformação mecânica e o resfriamento brusco para total transformação martensítica. O estágio de transferência do forno para a prensa pode promover alguma oxidação do aço. A aplicação de revestimentos ao blanque evita esse fenômeno. O revestimento Al-Si tem sido o mais aplicado. Paralelamente, estudos de revestimentos alternativos como o $\mathrm{Zn}$-Ni estão sendo realizados. Sabe-se que o aquecimento favorece a difusão dos elementos químicos que resulta na formação de intermetálicos entre os elementos presentes no revestimento e no substrato. Este estudo teve o objetivo de caracterizar as fases presentes em amostras estampadas e revestidas por Zn-Ni e Al-Si pela da técnica de difração de raios X. Não foram identificadas fases sugeridas pela literatura como $\mathrm{Zn}-\mathrm{Fe}, \mathrm{Zn}-\mathrm{Ni}-\mathrm{Fe}$ ou A-ISi-Fe. Mesmo assim a difração de raios $\mathrm{X}$ detectou a presença de $\mathrm{ZnO}$ e $\alpha-\mathrm{Fe}$ para a chapa de aço revestida com Zn-Ni e para a chapa de aço revestida com Al-Si, a presença de $\mathrm{Al}_{5} \mathrm{Fe}_{2}, \mathrm{AlFe}_{3}$ e $\alpha-\mathrm{Fe}$. 


\section{Introduction}

The application of hot stamped components in automotive industry is steadily increasing. It is a strategic product to help the automakers to achieve the INOVAR - AUTO targets regarding fuel consumption and emissions. The aim is to produce lighter and safer vehicles, and then reduces the $\mathrm{CO}_{2}$ emissions [1].

Press hardened steels (PHS) are boron-manganese steels. They are usually used in hot stamping process achieving after processing a tensile strength around $1500 \mathrm{MPa}$. Moreover, the spring back effect is not seen in the shaping process as a consequence of steel chemical composition combined with high temperatures [2]; [3] [4].

The hot stamping process consists in heating a steel blank at total austenitization temperatures and to transfer the blank into the press tooling for forming and fast cooling to fully martensitic transformation, as shown in Fig. 1. At the beginning of the process the steel has around $600 \mathrm{MPa}$ of tensile strength; at the end it increases to $1500 \mathrm{MPa}$. The blank transfer from the furnace to the press might promote some steel oxidation. In order to avoid this phenomenon, coatings are applied on the blank [5]; [6].

The Al-Si coating has been the most applied on PHS by hot dip. The bath consists in $10 \%$ in mass of silicon in aluminum. However, it is a patented material developed by ArcelorMittal known as USIBOR. Thus, alternative coatings zinc base, have been developed. $\mathrm{Zn}-\mathrm{Ni}$ is one of alternative to $\mathrm{Al}-\mathrm{Si}$; it is an electrodeposited coating, which consists in around $15 \%$ in mass of nickel [5]; [6]. It is known that the heating causes chemical elements diffusion that results in intermetallics formation amongst the elements presents in the coating and base metal [5].

The present study had the objective of characterizing the formed phases in samples coated with Al-Si and $\mathrm{Zn}-\mathrm{Ni}$ after hot stamping, through $\mathrm{X}$-ray diffraction technique (XRD).

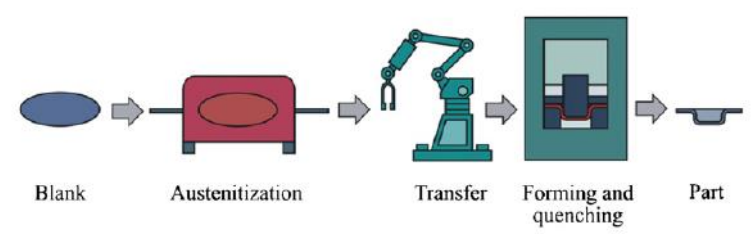

Figure 1. Schematic drawing of the hot stamping process [6].

\section{Experimental}

\subsection{Materials}

The samples were removed from the B - pillar inner, from a commercial and experimental parts of the 22Mn5B steel plate $1.2 \mathrm{~mm}$ thick. Two series of samples were taken: Sample I: Zn-Ni coated (20x20 $\left.\mathrm{mm}^{2}\right)$. Sample II: Al-Si coated $\left(20 \times 20 \mathrm{~mm}^{2}\right)$. Due to the shape of the part, it was not possible to obtain totally flat samples.

\subsection{Methods}

X-ray diffraction was undertaken at Bragg-Brentano geometry, with $\mathrm{Cu}$ anode. The angle of scanning was $(2 \Theta): 4^{\circ}-70^{\circ}$.

\section{Results and discussion}

Fig. 2 shows the result of $X$ ray diffraction pattern for sample I, Zn-Ni coated.

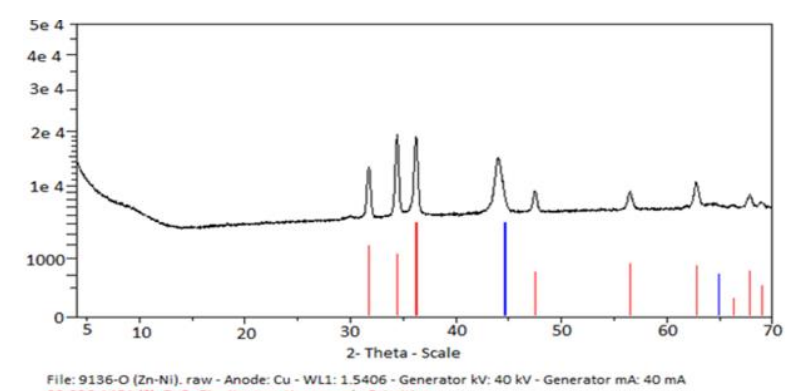

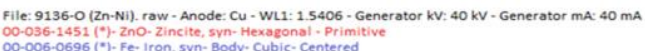

Figure 2. X-ray diffraction pattern of $\mathrm{Zn}-\mathrm{Ni}$ coated plate showing the presence of $\mathrm{ZnO}$ and $\mathrm{a}-\mathrm{Fe}$.

The diffraction pattern of $\mathrm{Zn}-\mathrm{Ni}$ coating only shows the presence of $\mathrm{ZnO}$ and $\alpha-\mathrm{Fe}$. This result might not show all the present phases because the sample was not totally flat, as it is required according to Bragg's law. An important observation is the absence of phases 
composed by $\mathrm{Zn}-\mathrm{Ni}$ or $\mathrm{Zn}-\mathrm{Fe}-\mathrm{Ni}$. Kondratiuk et al showed in their study the presence of $\mathrm{Y}-\left(\mathrm{Ni}_{5} \mathrm{Zn}_{21}\right)$ intermetallic, however this phase was not observed in the present study [5].

Fig. 3 shows the result of X-ray diffraction pattern for sample II, Al-Si coating.
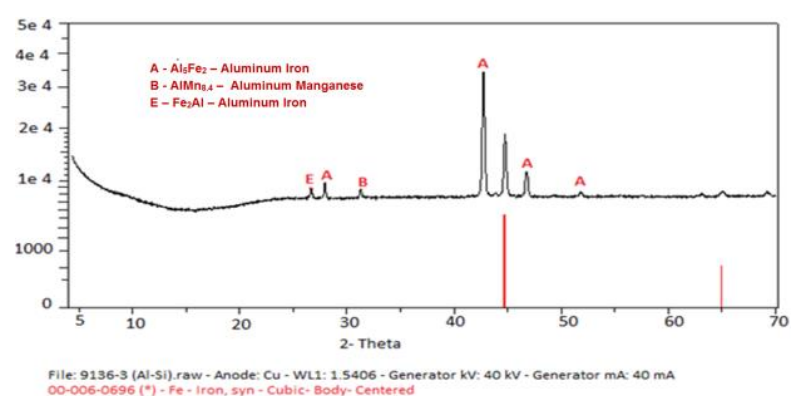

Figure 1. X-ray diffraction pattern of Al-Si coating showing the presence of $\mathrm{Al}_{5} \mathrm{Fe}_{2}$ (peak A) $\mathrm{AlFe}_{3}$ (peak E) and $\alpha-F e$.

The corresponding diffractogram for sample II shows the presence of $\mathrm{Al}_{5} \mathrm{Fe}_{2}$ (peaks A) $\mathrm{AlFe}_{3}$ (peak E) and $\alpha-$ Fe. $\mathrm{Al}_{5} \mathrm{Fe}_{2}$ is a brittle phase and it may promote cracks in coating layer. On the other hand, $\mathrm{AlFe}_{3}$ improve the corrosion resistance and it shows higher ductility in comparison with $\mathrm{Al}_{5} \mathrm{Fe}_{2}$ [7]. The condition of sample might imply in the absence of phases composed by Al$\mathrm{Fe}-\mathrm{Si}$. As reported by Windmann et al the silicon occupies a vacancy in $\mathrm{Al}_{5} \mathrm{Fe}_{2}$ phase, or it may increase the amount of phase $\mathrm{Al}_{8} \mathrm{Fe}_{2} \mathrm{Si}$ [6]. The phase $\mathrm{AlMn}_{8.4}$ (peak B) was identified, but information about this phase was not found in literature.

\section{Conclusion}

In respect to sample I, $\mathrm{Zn}-\mathrm{Ni}$ coated steel plate, $\mathrm{ZnO}$ was observed by X-ray diffraction as expected. However, phases composed by Zn-Fe or Zn-Fe-Ni were not identified.

The corresponding X-ray diffraction patter of sample II, $\mathrm{Al}-\mathrm{Si}$ coated steel plate, shows the phases $\mathrm{Al}_{5} \mathrm{Fe}_{2}$, $\mathrm{AlFe}_{3}$ and $\mathrm{AlMn}_{8.4}$, but the reported phases composed by $\mathrm{Al}-\mathrm{Fe}-\mathrm{Si}$ were not identified.

Even so X-rays diffraction is an important technique for characterization of crystalline materials, mainly during product development.

\section{Acknowledgments}

The authors would like to thank: CPNq Process $n$. 400870/2014-2, General Motors of Brazil, USIMINAS, UFES and IPEN.

\section{References}

[1] Brazil's Inovar-Auto Incentive Program. Available in: <http://www.theicct.org/sites/default/files/publications/IC CTupdate_Brazil_InovarAuto_feb2013.pdf >. Accessed in: 15 Mar. 2015.

[2]GORNI, A. New tendencies for the hot press stamping process. 2011. Available in: <http://www.gorni.eng.br/Gorni_CongCCM_2011.pdf>. Accessed in: 7 Apr. 2015. (In Portuguese)

[3] McCALLION, R. Manufacturing with UHSS. 2012. Available in:

$<$ http://www.automotivemanufacturingsolutions.com/pro cess-materials/manufacturing-with-uhss $>$. Accessed in: 4 Apr. 2015.

[4] VAN TOL, R. T. Microstructural evolution in deformed austenitic TWinning induced plasticity steel. Ph.D. Thesis Delft University, 2014.

[5] KONDRATIUK et al. Zinc coatings for hot sheet metal forming: Comparison of phase evolution and microstructure during heat treatment. Surface \& Coatings Technology, v. 205, i. 17-18, p. 4141-53, 2011.

[6] WINDMANN et al. Formation of intermetallic phases in Al- coated hot- stamped $22 \mathrm{MnB} 5$ sheets in terms of coating thickness and Si content. Surface \& Coatings Technology, v. 246, p. 17-25, 2014.

[7] BIANCHI, E.C. et al. Al-Fe coating deposited by thermal spray, the in-situ reaction of elemental powders Fe and Al. In: Seminário de Pós-Graduação em Engenharia Mecânica 4, Bauru - Brazil, 2010. (In Portuguese) 